\title{
ZARÁNDOKLAT, TURIZMUS ÉS ÉPÍTÉSZET KOLOZS MEGYÉBEN A MÁRIA-ÚT MENTÉN
}

\section{PILGRIMAGE, TOURISM AND ARCHITECTURE IN CLUJ COUNTY, NEAR THE „WAY OF MARY”}

\author{
Orbán György ${ }^{1}$, Talpas János ${ }^{2}$ \\ ${ }^{I}$ Erdélyi Múzeum-Egyesület, 400009 Kolozsvár/Cluj-Napoca Napoca/Jókai u. 2-4, \\ levelezésicim,orban@esvvv.com \\ ${ }^{2}$ Babeș-Bolyai Tudományegyetem, Földrajz Kar, 400006 Kolozsvár/Cluj-Napoca, \\ Str.ClinicilorNr.5-7.talpasjanos@gmail.com
}

\begin{abstract}
The scope of the paper is to present conclusions of the development and research of pilgrim centers and building surveying near the „Way of Mary”, from the past three years.

Keywords: pilgrimage, tourism, architecture

\section{Összefoglalás}

A dolgozat célja az elmúlt három évben a Mária-út mentén kialakított zarándokszállások kutatása és azt megelőző épületfelmérések bemutatása és eredményeinek összegzése.
\end{abstract}

Kulcsszavak: zarándoklat, turizmus, épitészet

\section{A zarándoklatok eredete}

Bhardway [3] összegezte azokat a minimális feltételeket, amelyeknek teljesülniük kell ahhoz, hogy zarándoklatról beszélhessünk. Szavai szerint: ,egy vallásos meggyőződéssel rendelkező egyén, egy szent hely vagy cél, amit kitüz maga elé, és a fizikai tett, ami által végrehajtja az utazást." Közös tulajdonsága a zarándoklatoknak és a hitbeli meggyőződésből megtett utazásoknak az, hogy minden esetben szükség van egy utazás, vándorlás megtételére.

\section{A zarándoklat infrastruktúrája}

Stoppford [4] a zarándoklat megtételéhez szükséges infrastruktúrákat határozta meg. Elsődlegesek maguk a szentélyek (melyek, mint hely magukban rejtették vagy szimbolikusan hordozták a szent motivációt), de természetesen az ,utak, hajók, hidak, zarándokszállások, korházak, temetők, védett menedékhelyek" is elengedhetetlenek voltak. Ugyanúgy számos szolgáltatásra is szükség volt, mint élelmezés, víz, emléktárgyak, ruházat és védelem. Stoppford [4] alapján saját értelmezésben összefoglalva [8] a zarándoklatok két nagy infrastruktúrával rendelkeznek: a szellemi (mely a motiváció) és a fizikai (melyet Stoppford világított meg). A fizikai infrastruktúra három nagy fejezetre bontható:

- útvonal és út;

- szállás és szolgáltatás; 
- szentélyek (mint az immateriális infrastruktúra helye, megnyilatkozásai).

A dolgozatban a zarándoklat, szállás és szolgáltatás fizikai infrastruktúrájával foglalkoztunk, a másik kettőt csak a kontextusba helyezés kedvéjért érintettük.

\section{A Mária-zarándokút}

A Mária-út a Santiago de Compostellába vezető nagy nyugat-európai Szent Jakab-zarándokúthoz hasonlóan szellemi és kulturális motivációval rendelkezők vagy csak egyszerủen a kirándulni vágyók útvonala. Így határozta meg a kelet-európai Mária-kultusz zarándokhelyeit összekötő úthálózatot a Mária Út Egyesület.
A Mariazellt Csíksomlyóval és Czestochowát Medjugorjéval összekötő zarándokút erdélyi szakaszának végcélja Csíksomlyó. Ugyanakkor, mint minden zarándokút, számos útvonala és útiránya van, alapvetően a valamilyen helyi és egyetemes spiritualitással rendelkező helyeket köti össze, melyeknek átfogó tematikája a Mária-tisztelet. Az útvonalat különböző motivációjú emberek használják többnyire kisseb csoportokban vagy magánosan. A zarándokút jellegéhez tartozik a gyalogos, illetve biciklis vándorlás.

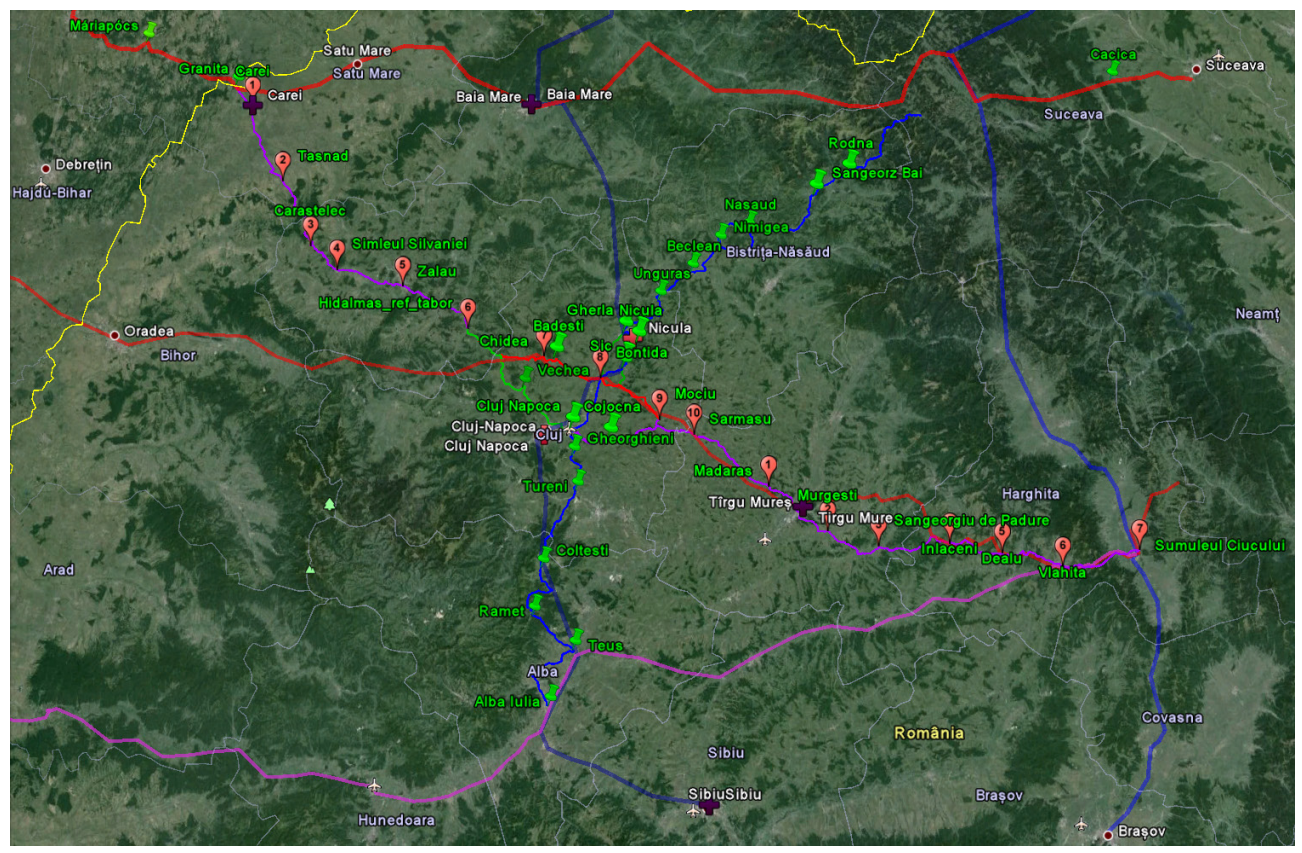

1. ábra. A Mária-zarándokút erdélyi szakaszai [8]

\section{Szállások és szolgáltatások - építészeti igény}

Egy nap alatt a zarándokok gyalogosan átlag legtöbb $30 \mathrm{~km}$ távolságot tudnak megtenni. Ez a tény évezredek óta változatlan, és így a gyalogos zarándoklatok materiális infrastruktúrájának egyik meghatározó alapeleme, hogy megfelelő távolságokon a zarándokok megszállhassanak és étkezhessenek, illetve a kapcsolódó szolgáltatásokat igénybe vehessék. 
5. A szállások kialakításának lehetőségei - épületfelmérések

A Mária-út erdélyi szakaszában, különösen Kolozsvár környékén, de egészen Óradnától Nagyszebenig vagy Hídalmástól Jobbágyfalváig kifejezetten Mária-utas zarándokszállások nem voltak kialakítva. A zarándokokat eltérő körülmények között fogadták a jószándékú helyi lakosok, különböző egyházak és szervezetek. Ezért vált szükségessé egy standard körülményeket biztosító, előre látható szálláshálózat kialakításának a lehetöségét bemutatni. Az épületállomány akár részleges megismerése és felmérése, építészeti dokumentálása is éveket vett igénybe.

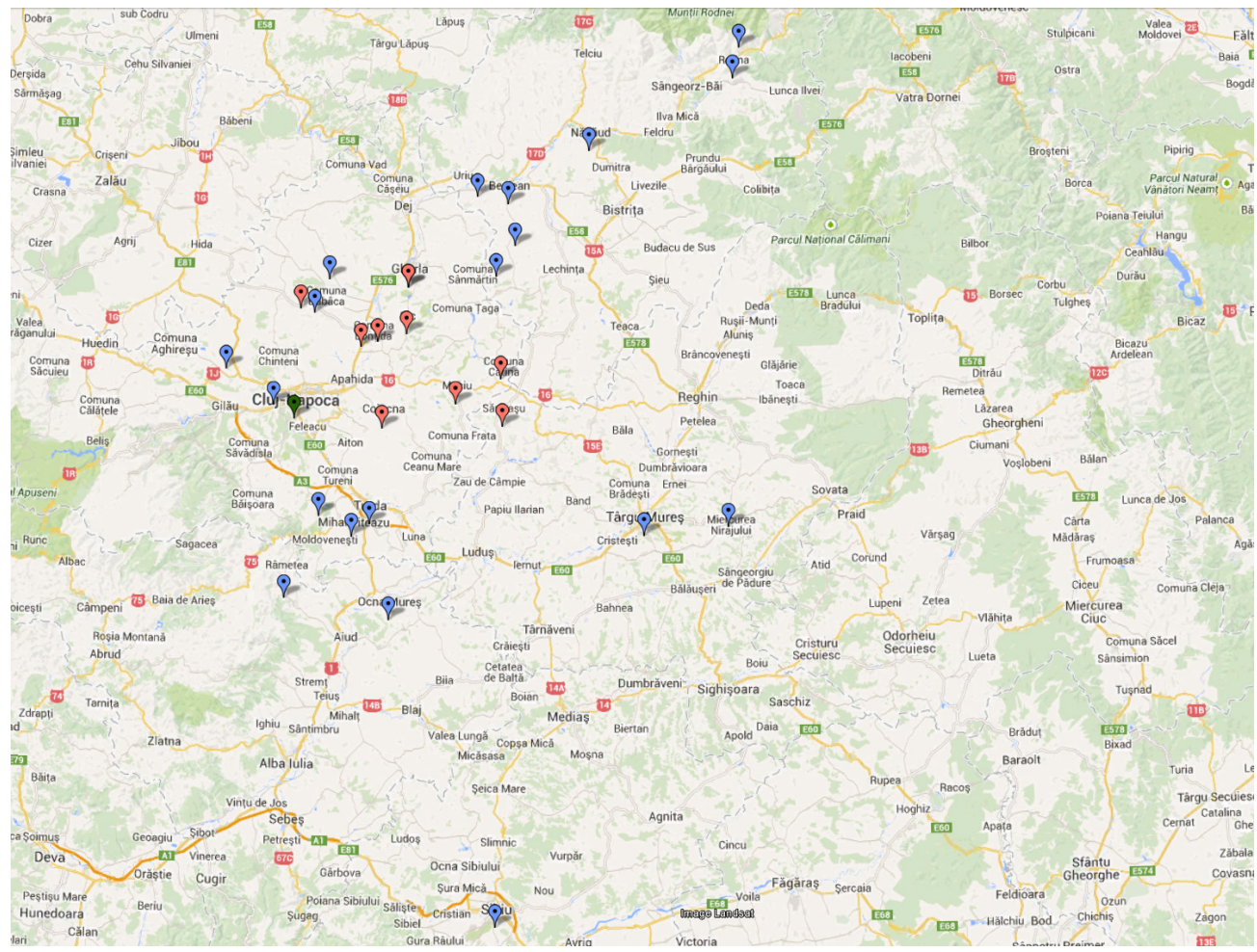

2. ábra. Épületfelmérések: 2011 és 2013 zöld, 2012 piros, 2013 kék

\section{1. Épületfelmérések 2011-ben}

Az Erdélyi Múzeum-Egyesület (EME), az Erdélyi Ferences Rendtartomány, a Budapesti Műszaki és Gazdaságtudományi Egyetem (BME), a Kolozsvári Müszaki Egyetem (KME) és a Romániai Építészek Rendjének segítségével került sor a kolozsvári ferences kolostor és templom felméré- sére. A munka során az előző évek anayagát is felhasználtuk. A felmérések anyagát az EME digitális tervtárában rögzítettük.

\section{2. Épületfelmérések 2012-ben}

A BME, a Szamosújvári Katolikus Plébánia, az EME, a KME és a Gyulafehérvári Római Katolikus Érsekség segítségével került sor épületfelmérésre több településen 
Kolozs megye északi részén. Felmértük [1] a katolikus egyház és esetenként a református egyház ingatlanjait a következő településeken:

- Szamosújvár (5 épület): ferences kolostor (felhasználva a meglevő anyagot), örmény székesegyház, örmény Salamontemplom, református templom, örmény ház, örmény plébánia;

- Kide (2 épület): plébánia, református vendégház;

- Bonchida (4 épület): református parókia, református templom, református vendégház, plébánia;

- Szék (2 épület): plébánia, templom;

- Kolozs (2 épület): templom, katolikus óvoda;

- Mócs (2 épület): plébánia, templom;

- Katona (3 épület): katolikus rendelöépület, boltépület, harangláb;

- Nagysármás (1 épület): kápolna,

- Válaszút (1 épület): kápolna.

A felmérések alkalmával, turistajelzésként, megközelitőleg $180 \mathrm{~km}$ hosszan, a terepen kijelöltük (a Mária Út Egyesület iránymutatása szerint) a zarándokutat.

\section{3. Épületfelmérések 2013-ban}

A BME, a KME, az EME és a helyi plébánosok segítségével került sor épületfelmérésre Erdélyben a Mária-zarándokút mentén. Felmértük [2] a katolikus egyház és esetenként a református egyház ingatlanjait a következö településeken:

- Óradna (4 épület): görög katolikus templom, görög katolikus templomrom, plébánia, templom;

- Radnaborberek (1 épület): templom;

- Naszód (1 épület): templom;

- Vice (3 épület): református templom, templom, plébánia;

- Csicsókeresztúr (2 épület): templom, plébánia;

- Bethlen (2 épület): templom, plébánia;

- Apanagyfalu (1 épület): plébánia;
- Bádok (2 épület): régi iskola, református templom;

- Magyarsárd (1 épület): romtemplom;

- Kisbács (1 épület): templom;

- Szamosújvár (1 épület): református ravatalozókápolna;

- Kolozsvár (1 épület): bérpalota,

- Torda (5 épület): ferences kolostor, ferences templom, templom, református iskola, református ravatalozókápolna;

- Marosújvár (1 épület): templom,

- Peterd (1 épület): zarándokház;

- Torockószentgyörgy (1 épület): templom és plébánia;

- Szentmihály (2 épület): kápolna, plébánia;

- Sínfalva (1 épület): plébánia;

- Marosvásárhely (1 épület): jezsuita templom;

- Jobbágyfalva (3 épület): templom, plébánia, melléképület;

- Nagyszeben (4 épület): a Tereziánum temploma, jezsuita templom, kápolna, ravatalozókápolna.

\section{Szállás és szolgáltatás, konkrét példák}

Az épületfelmérések célja a szálláshelyek kialakítására alkalmas és rendelkezésre álló épületállomány megismerése és dokumentálása. 2011-2012-ben a szamosújvári katolikus plébánia számára kifejlesztett és elkészített zarándokszállásterv és meghatározott építészeti program alapján [5], a felmért és alkalmas épületek zarándokszállássá való áttervezése a felmérések eredménye.

\subsection{Szamosújvár}

A szamosújvári új plébánia tervezésében a tervezési program része volt egy zarándokszállás kialakítása is. Itt került sor a többi zarándokszállás funkcionális sémájának is alapját képezö, konkrét és gyakorlatba ültetett alappélda megtervezésére. A tervezés után, az építkezés 2013-ban el is kezdődött és a tervek szerint 2018-ig tart. 


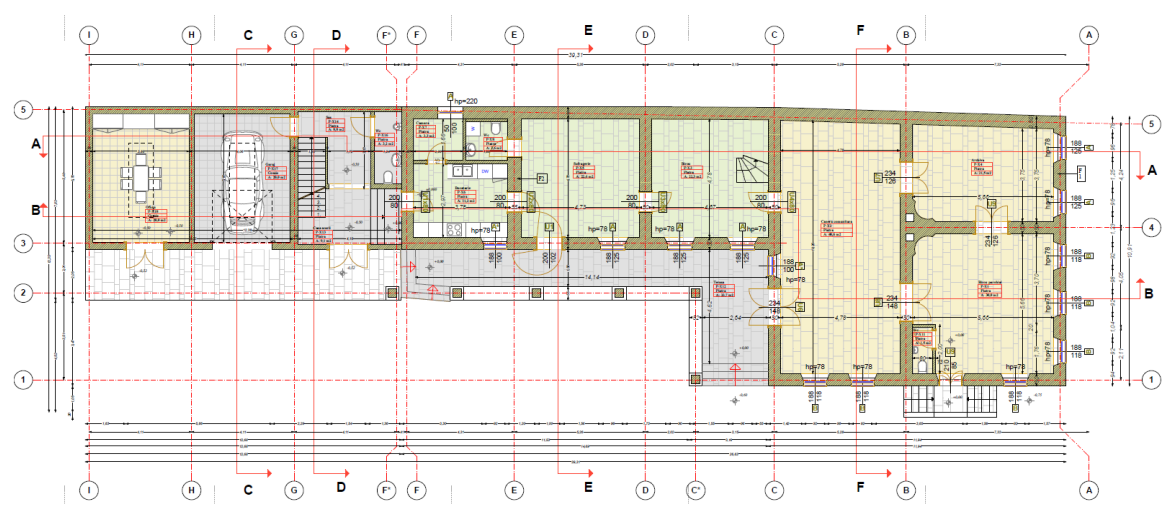

3. ábra. Szamosújvár-zarándokszállás és plébánia-földszint

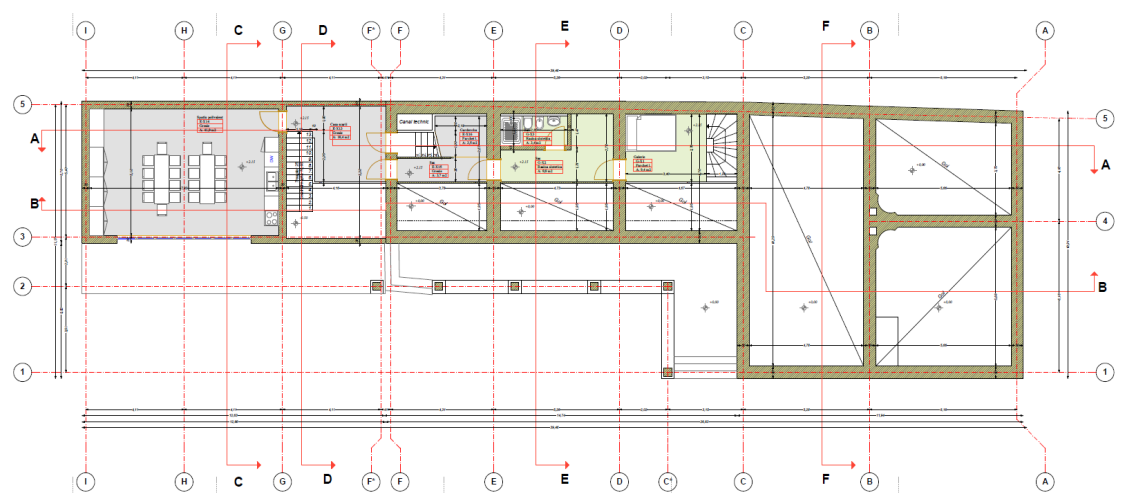

4. ábra. Szamosújvár-zarándokszállás és plébánia-félemelet

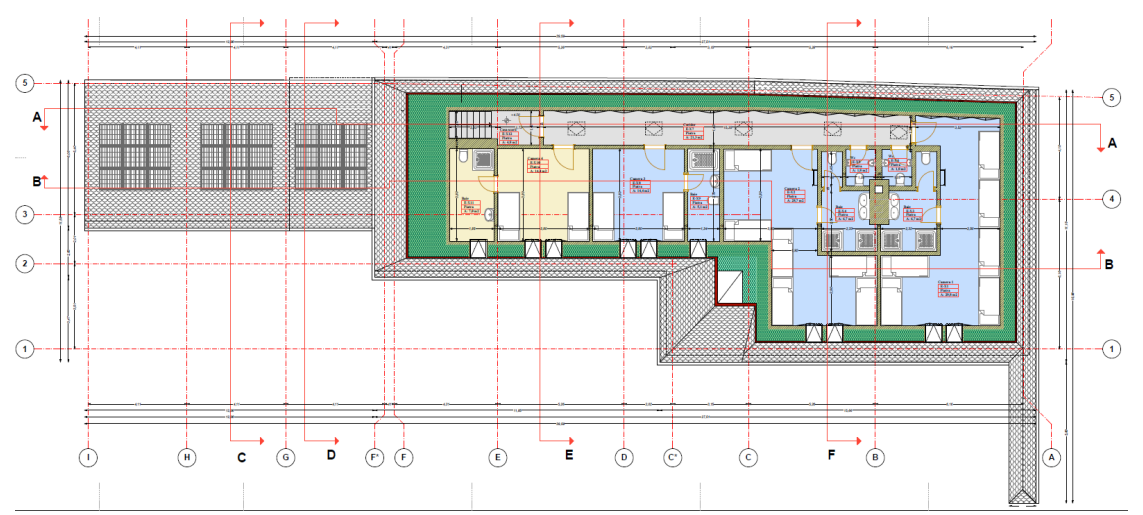

5. ábra. Szamosújvár-zarándokszállás és plébánia - tetőtér 


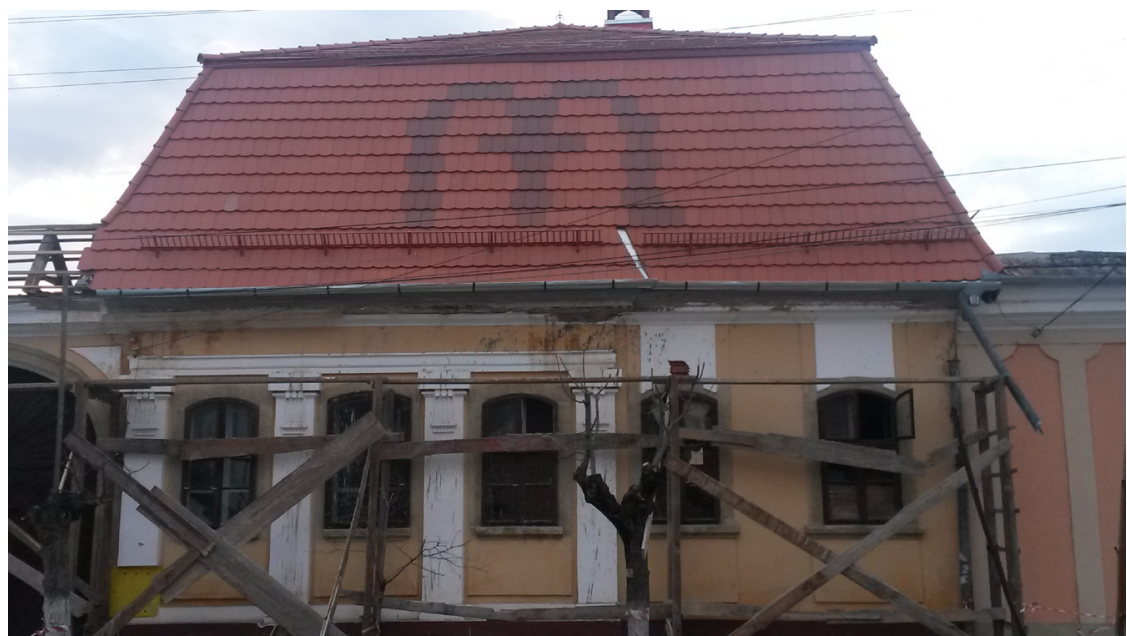

6. ábra. Szamosújvár-zarándokszállás és plébánia - épittkezés

A zarándokszállások funkcionális sémája [6]. A minimális funkcionális követelmények (30 fó részére): szállás, két nagy hálóterem, zuhanyzók (4 db.) és mellékhelyiségek (4 db.), egyéni szobák igényesebb utazók számára, saját fürdőszobával; szolgáltatások: étkezőterem, saját kiszolgálás vagy ellátás, mosókonyha és szárító; adminisztráció: a fogadásra alkalmas iroda, ruha- és csomagtároló.

\subsection{Kolozs}

A kolozsi plébánia terveit a turisztikai potenciál miatt emeltük ki [7]. A kolozsi sósfürdő mint turisztikai vonzerő a zarándokszállás kihasználtságát segít növelni. A zarándokszállás programja itt annyiban módosult, hogy a szálláshelyek kialakításában az egyéni (kisebb szobák) kialakításával bíztosítottuk a szálláshelyek számát. Így egy magasabb komfort biztosítása mellett a szállást a sósfürdőt látogatók is igénybe vehetik. A fenti megfontolások alapján ezen a helyszínen 3 , egymást akár kiegészítő tervjavaslat is született.

A plébánia mellett kialakítandó új épület: 1 . változat, befogadóképesség 30 fö.

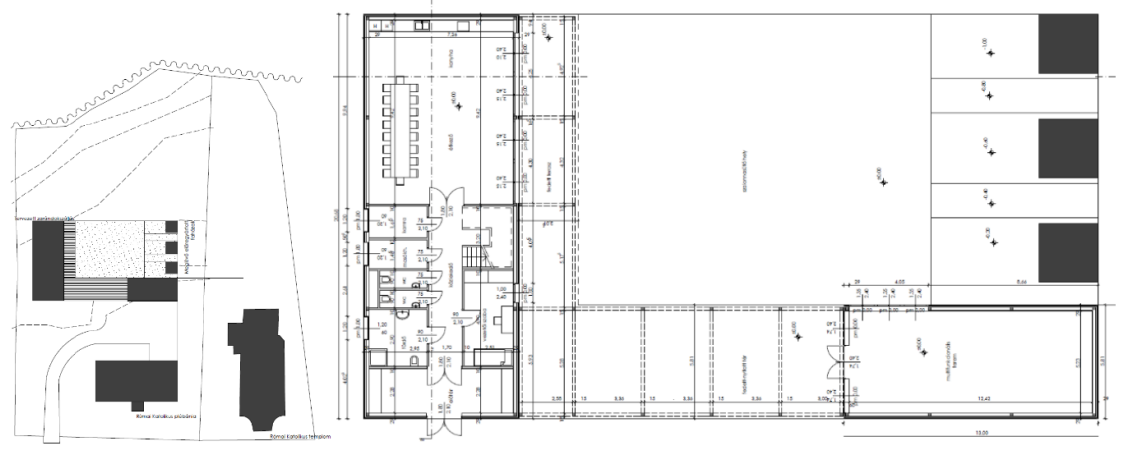

7. ábra. Kolozs - 1. változat - földszint 


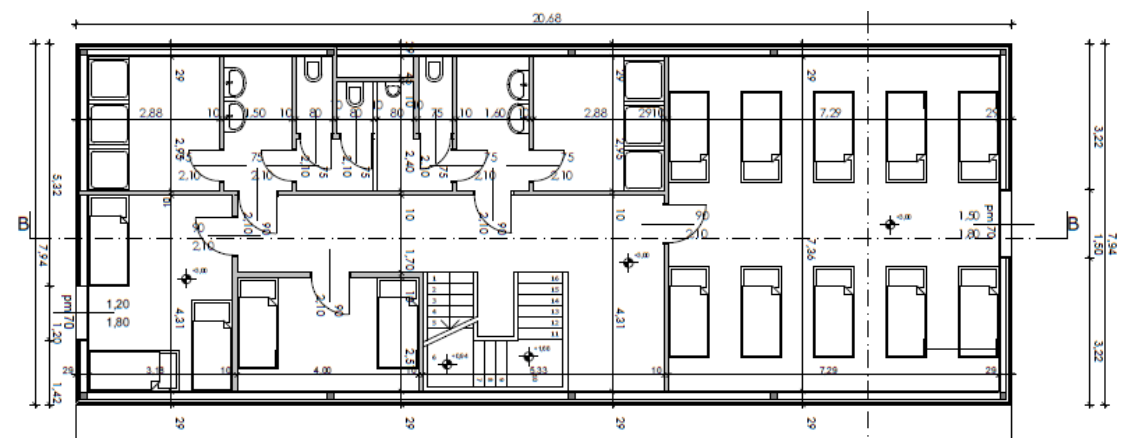

8. ábra. Kolozs - 1. változat-emelet

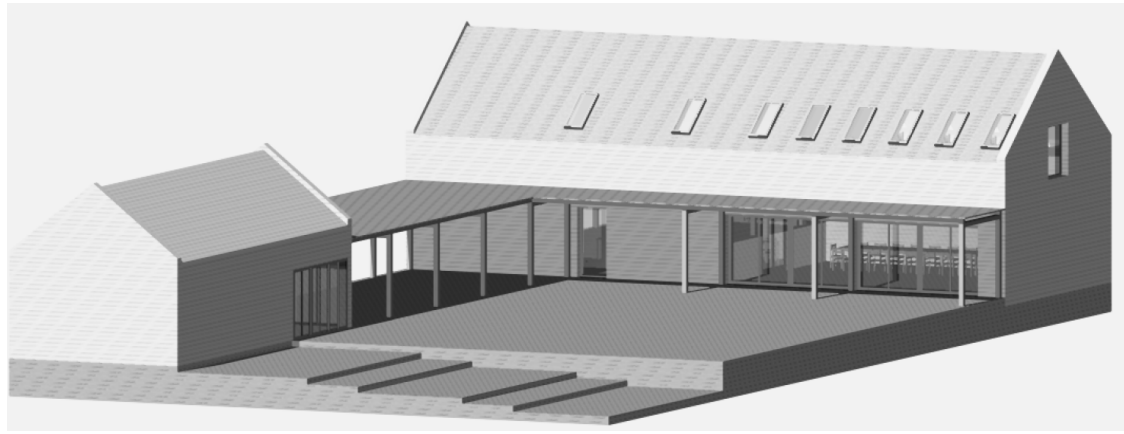

9. ábra. Kolozs -1.változat - látványterv

\subsection{Peterd}

A felmérések nem csak Mária-utas zarándokszállások terveinek kidolgozásához járultak hozzá. Peterden, a felmérések eredményeként egy gyerektáboroztatásra alkalmas épület jött létre. Az épület természetesen alkalmas zarándokok befogadására vagy különböző tematikus programok szervezésére is vagy alkalmi turistacsoportok fogadására. A helyi adottságok miatt, mivel közvetlenül a Tordai-hasadék bejáratánál fekszik, felhasználási lehetőségei rendkívül kedvezőek. Kapacitását tekintve akár több autóbusznyi embert is képes befogadni.

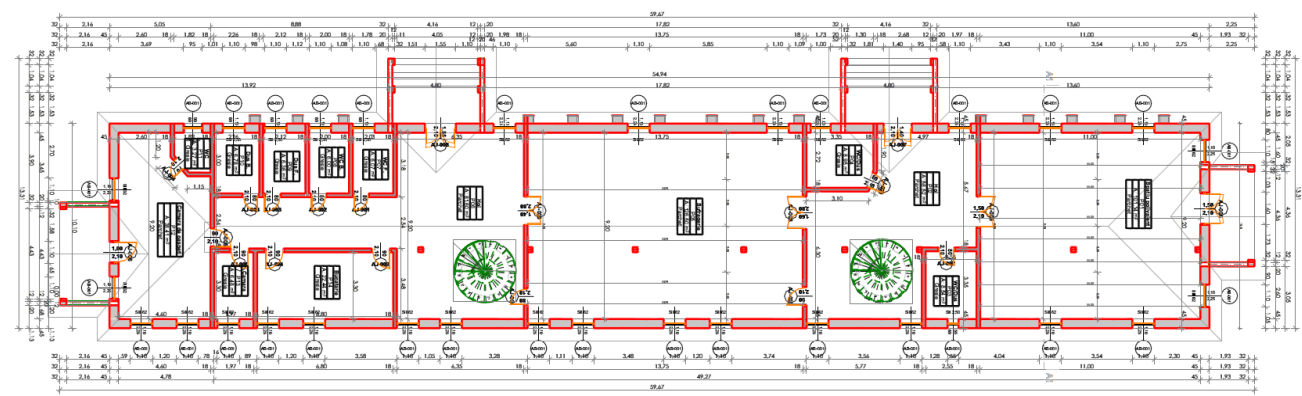

10. ábra. Peterd-vendégház - földszínt 


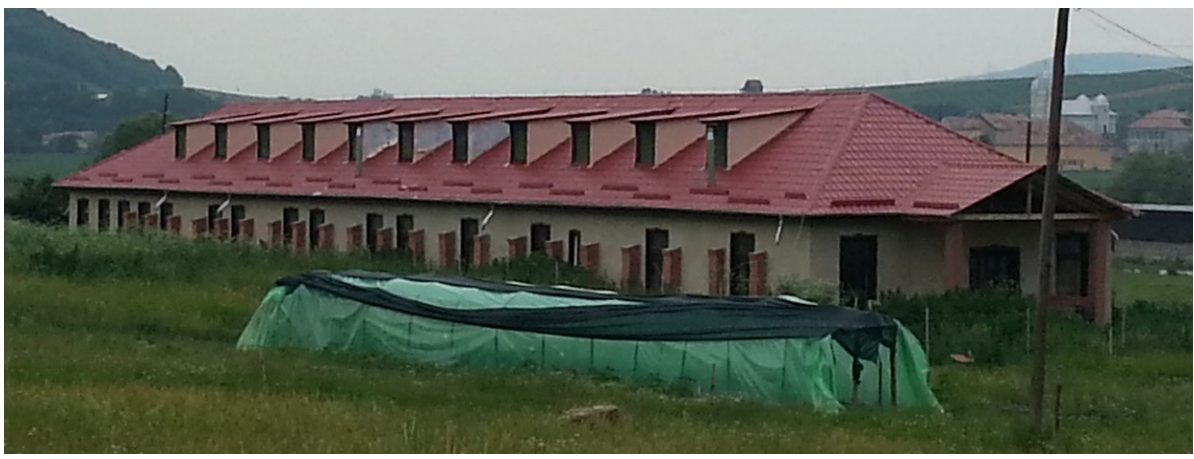

11. ábra. Peterd-vendégház-fénykép

\section{Következtetések}

Az építészeti felmérések a megvalósított és a tervezett példák alapján hasznosnak bizonyultak. Kivitelezhetőségüket a gyakorlat igazolja. A turisztikai és zarándokút fejlesztése így közösen egy reális programnak bizonyul, melyet a jövőben pályázati dokumentációvá és fundamentális fejlesztési keretté lehet alakítani [8] a helyi közösségek és az egyház együttmüködéseként.

\section{Szakirodalmi hivatkozások}

[1] Budapesti Müszaki Egyetem, Építészettörténeti és Mủemléki Tanszék - Mezős Tamás, Orbán György, Starowicz Annamária és egyetemi hallgatók: Diákok nyári felmérö és tervezö gyakorlata: Mária-út - plébániák és templomok felmérése és tervezése. 2012.

[2] Budapesti Müszaki Egyetem, Építészettörténeti és Műemléki Tanszék - Mezős Tamás, Orbán György, Bodó Balázs és egyetemi hallgatók: Diákok nyári felmérő és tervezö gyakorlata: Mária-út - plébániák és templomok felmérése és tervezése. 2013.

[3] Elsner, J., Rutherford, I.: Pilgrimage in Graeco-Roman and Early Christian Antiquity: Seeing the Gods. Oxford University Press, Oxford, 2007. 353.

[4] Stopford, J.: Some Approaches to the Archaeology of Christian Pilgrimage. In:
World Archaeology vol. 26. 1994. Nr. 1. 5772.

[5] Orbán, Gy.: A Római Katolikus Erdélyi Egyházmegye ingatlanvagyonának felmérése és hasznositása - Mária Zarándokút. XVII. Fiatal Müszakiak Tudományos Ülésszaka (FMTÜ), EME kiadó, Kolozsvár, 2012. 263266.

[6] Talpas, J., Orbán, Gy., Márton, L.: Egyházi ingatlanok hasznositási lehetőségei a Máriazarándokút Északkelet-Kolozs megyei szakaszán. XVIII. FMTÜ, EME kiadó, Kolozsvár, 2013. 401-406.

[7] Orbán, Gy.: Sustainability aspects, of the roman-catholic ecclesiastic buildings situated on the pilgrim road "Way of Mary" in Transylvania on the north-east region of Cluj country. Proceedings of the International Association for Shell and Spatial Structures (IASS) WG 18 International Seminar on Environmentally Compatible Structures (ECS) November 7-9 2013. Cluj-Napoca, Romania, UTPRESS, Kolozsvár, 2013. 115127.

[8] Orbán, Gy.: Analysis and valorisation of the built heritage of the roman-catholic church of transylvania within the pilgrimage route "Way of Mary". Doktori dolgozat, Kolozsvári Müszaki Egyetem, Kolozsvár, 2013. 53228. 